\title{
Seasonal and interannual variability of sedimentation and organic matter distribution in the Buor-Khaya Gulf: the primary recipient of input from Lena River and coastal erosion in the southeast Laptev Sea
}

\author{
A. N. Charkin ${ }^{1}$, O. V. Dudarev ${ }^{1}$, I. P. Semiletov ${ }^{1,2}$, A. V. Kruhmalev ${ }^{1}$, J. E. Vonk ${ }^{3}$, L. Sánchez-García ${ }^{3}$, E. Karlsson ${ }^{3}$, \\ and $\ddot{O}$. Gustafsson ${ }^{3}$ \\ ${ }^{1}$ Pacific Oceanological Institute (POI), Russian Academy of Sciences, Vladivostok, Russia \\ ${ }^{2}$ International Arctic Research Center, University of Alaska Fairbanks, USA \\ ${ }^{3}$ Department of Applied Environmental Science (ITM) and the Bert Bolin Centre for Climate Research, Stockholm \\ University, Sweden
}

Received: 8 February 2011 - Published in Biogeosciences Discuss.: 28 February 2011

Revised: 29 August 2011 - Accepted: 31 August 2011 - Published: 14 September 2011

\begin{abstract}
Climate warming is amplified in the land-sea system of the East Siberian Arctic, which also holds large pools of vulnerable carbon in permafrost. This coastal area is strongly influenced by sediment and carbon transport from both its large rivers and extensive erosion of Pleistocene permafrost along its coastline. This study is investigating the coastal fate of the sediment and organic carbon delivered to the Buor-Khaya Gulf, which is the first recipient of the overwhelming fluvial discharge from the Lena River and is additionally receiving large input from extensive erosion of the coastal ice-complex (permafrost a.k.a. Yedoma; loess soil with high organic carbon content). Both water column suspended particulate matter (SPM) and surface sediments were sampled at about 250 oceanographic stations in the Gulf in this multi-year effort, including one winter campaign, and analyzed for the distribution and sorting of sediment size, organic carbon content, and stable carbon isotope signals. The composition of the surface sediment suggests an overwhelmingly terrestrial contribution from both river and coastal erosion. The objective of this paper is to improve our understanding of the seasonal (i.e., winter vs summer) and interannual variability of these coastal sedimentation processes and the dynamics of organic carbon (OC) distribution in both the water column SPM and the surface sediments of the BuorKhaya Gulf.
\end{abstract}

Based on data collected during several years in the period 2000-2008, two different sedimentation regimes were revealed for the Buor-Khaya Gulf, the relative importance of each at a given time depend on hydrometeorological conditions, the Lena River water discharge and sea-ice regime: Type 1 erosion-accumulation and Type 2 accumulation.

The Type 1 erosion-accumulation sedimentation regime is typical (2000-2006) for the ice-free period of the year (here considered in detail for August 2005). Under such conditions terrigenous sources of SPM and particulate organic carbon (POC) stem predominantly from river discharge, thermal erosion of coastal ice-complex and remobilized bottom sediments. The Type 2 accumulation sedimentation regime develops under ice-covered conditions, and only occasionally during the ice-free period (August 2008). In Type 2 winter, combined terrigenous and marine-biogenic SPM and POC sources are dominating due to relatively low overall terrigenous input (April 2007). In Type 2 summer, river alluvium becomes the major SPM and POC source (August 2008). The water column SPM and POC loadings vary by more than a factor of two between the two regimes. This study underscores the necessity of multi-year investigations to better understand the functioning of the primary recipient of terrestrially expulsed matter in the East Siberian Arctic.

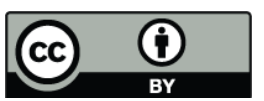

Correspondence to: A. N. Charkin

(charkin@poi.dvo.ru)

Published by Copernicus Publications on behalf of the European Geosciences Union. 


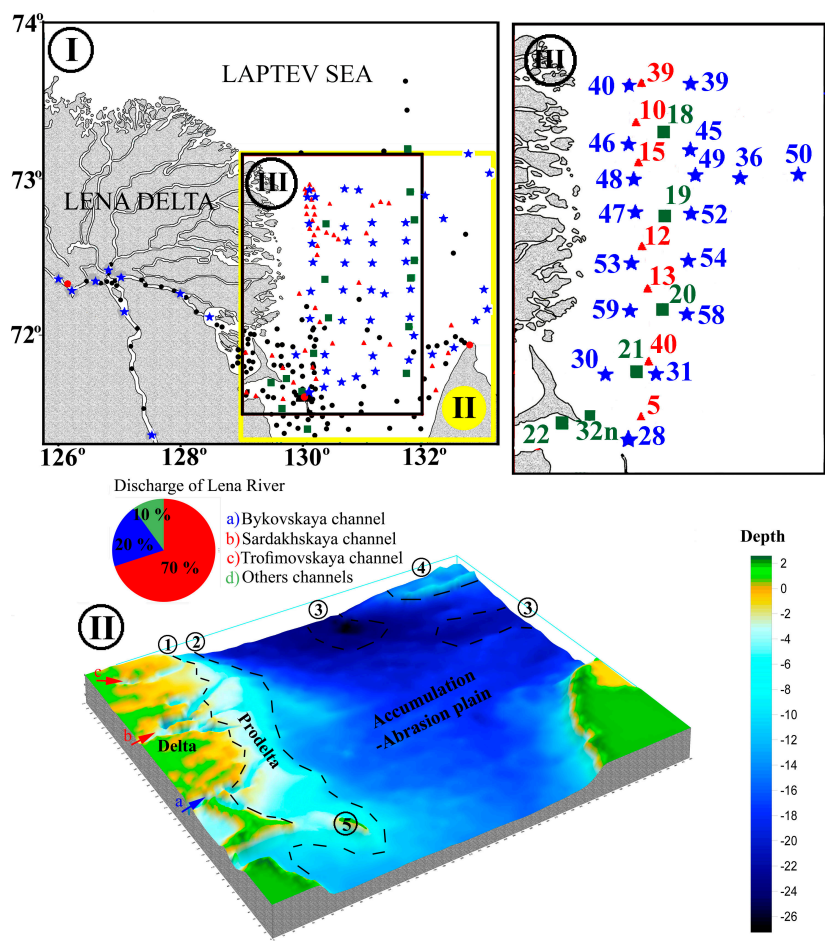

Fig. 1. Study area. I. Location of oceanographic stations from 1999 to 2008 years (black dots - oceanographic stations, red dots - coast observations). II. Flow chart of geomorphological structure of the Buor-Khaya Gulf: 1 - marine margin of delta, 2 - prodelta foot, 3 accumulative plain, 4 - relict of subaerial land forms, 5 - Muostakh Island. III. Oceanographic station transects of vertical SPM and salinity distributions.

\section{Introduction}

The Arctic Ocean receives $>10 \%$ of the global river sediment discharge while only hosting $1 \%$ of the total ocean volume. The northeast Siberian land-shelf region is one of the areas on earth experiencing the strongest climate warming (e.g. Richter-Menge and Overland, 2010). Furthermore, the East Siberian Arctic Shelf (ESAS) is the world's largest continental shelf sea system and it is unusually shallow making the coastal system strongly influenced by terrestrial input. Nevertheless, there is a shortage of interannual and seasonal investigations of the coastal processing of the delivered sediment and its associated carbon content in this region (most previous studies have provided a snapshot from a single expedition).

The Buor-Khaya Gulf in the SE Laptev Sea was targeted for this study as it is both the primary recipient of the Lena River discharge and a hotspot for erosional input from the thermo-abraded coastal ice-complex of Pleistocene permafrost. About $80-90 \%$ of the Lena River water and up to $85 \%$ of its sediment discharge enters the Buor-Khaya Gulf (Fig. 1) divided between the three eastern delta channels: the Sardakhsko-Trofimovskaya system $(60-75 \%$ of water dis- charge and up to $70 \%$ of sediment discharge), Bykovskaya (20-25\% of water discharge and $15 \%$ of sediment discharge), Olenekskaya and Tumatskaya (5-10\% of water discharge and $10 \%$ of sediment discharge) (Antonov, 1987; Sidorov, 1992; Ivanov et al., 1999) (Table 1). There are discussions concerning how much of the sediment transported by the Lena River actually reaches the Laptev Sea (Are et al., 2000). For example, one publication states that only 10-17\% of the sediment in the lower Lena River at Kyusur makes it through the Lena Delta (Alabyan et al., 1995), whereas another paper argues that essentially all suspended sediments reach the Laptev Sea (Rachold et al., 2000).

Up to $30 \%$ of the coastline of the Buor-Khaya Gulf is composed of the steep (up to $30 \mathrm{~m}$ ) relief of the ice-complex (yedoma), which is rapidly collapsing under thermal abrasion and accelerated wind/wave erosion due to the longer ice-free season and larger wave fetch. For instance, the coastline of Muostakh Island, located in the Buor-Khaya Bay, is retreating on average $11 \mathrm{~m} \mathrm{yr}^{-1}$ (Grigoryev and Kunitsky, 2000). The ice-complex is also widely spread within the Lena River Delta where its average annual retreat rate is 2 $3 \mathrm{~m} \mathrm{yr}^{-1}$ (Grigoryev, 1993). In the Laptev Sea, the annual supply of sedimentary material by coastal erosion is about $58.4 \times 10^{6} \mathrm{t} \mathrm{yr}^{-1}$ (Stein, et al., 2004) (Table 1). Thus, the sedimentary material of the eastern Laptev Sea coastal zone comes from two major sources: fluvial sediment discharge from the Lena River, and thermal collapse and erosional input from the coastline ice-complex (Stein, 2000; Stein et al., 2004; Rachold et al., 1999; Semiletov et al., 1999, 2000, 2011a; Mueller-Lupp et al., 2000; Dudarev et al., 2003, 2006a, b, c, Vonk et al., 2011, Gustafsson et al., 2011). In summertime the dominant source of $\mathrm{OC}$ is terrestrial carbon, while the marine biogenic carbon plays a small role in the Laptev Sea shallow oligotrophic waters (Heiskanen et al., 1996; Sorokin and Sorokin, 1996). Since hydrometeorological conditions and the increasing Lena water discharge varies interannually (Savelieva et al., 2000, Pipko et al., 2010; Semiletov et al., 2000, 2011a), it should be expected that the relative importance of these two sediment sources are also varying interannually, which in turn should be reflected in the composition of the water column suspended particulate matter (SPM) and of the bottom sediments (Charkin et al., 2010).

The objective of this paper is to improve our understanding of the seasonal (i.e., winter vs summer) and interannual variability of these coastal sedimentation processes and the dynamics of organic carbon (OC) distribution in both the water column SPM and the surface sediments of the Buor-Khaya Gulf. 
Table 1. Mean-annual water (1) $\left(\mathrm{km}^{3}\right)$ and sediment load discharge (2) $\left(10^{6} \mathrm{tyr}^{-1}\right)$ by the Lena River and the main arms of the Lena delta (Antonov, 1987; Ivanov et al., 1999) and sediment budget by coastal erosion (2) $\left(10^{6} \mathrm{t} \mathrm{yr}^{-1}\right.$ ) on the shelf of Laptev Sea (Stein et al., 2004).

\begin{tabular}{ccccccc}
\hline Lena River & $\begin{array}{c}\text { Sardakhsko-Trofimovskiy } \\
\text { channel }\end{array}$ & $\begin{array}{c}\text { Bykovskaya } \\
\text { channel }\end{array}$ & $\begin{array}{c}\text { Tumatskaya } \\
\text { channel }\end{array}$ & $\begin{array}{c}\text { Olenekskaya } \\
\text { channel }\end{array}$ & $\begin{array}{c}\text { Sediment budget by } \\
\text { coastal erosion }\end{array}$ \\
\hline 1 & 511 & 314 & 129 & 32.7 & 34.7 & - \\
2 & 18.4 & 11.6 & 3.58 & 1.92 & 1.25 & 58.4 \\
\hline
\end{tabular}

\section{Material and methods}

\subsection{Expeditions}

Observations and sampling were performed in the BuorKhaya Gulf (southeast Laptev Sea) on several separate expeditions using the mid-size hydrographic vessel Nikolai Kolomeitsev (2000), and the small vessels Auga (2005) and TB-0012 (2006-2008). In March-April 2007 an exploratory survey was performed on the land-fast sea ice to collect data for winter conditions using a transport caravan consisting of a caterpillar, a heavy all-terrain truck and a sled train, hosting laboratory and accommodations (Semiletov et al., 2011b). During the whole survey period 250 complex oceanographic stations were accomplished with the bulk of the marine data for this paper being collected in August 2005, March-April 2007 and August 2008 expeditions. Furthermore, observations and sampling were also performed at key sections of the coastline, including Muostakh Island, Buor-Khaya Cape and Lena Delta channels with samples taken from the tidal flat, the beach and up along the steep coastal abrasion cliff (Fig. 1). All the expeditions with specific sampling dates and type are listed in Table 2.

\subsection{Analytical methods}

Size composition of fine grained sediments and SPM was studied using a laser microanalyzer (Analysette 22, Fritsch $\mathrm{GmbH}$ ). Sieve analysis was used for coarse sediments examination (Petelin, 1961). Bottom sediment sizing was then performed on the basis of a three-component classification (Shepard, 1954) with the definitions of sand (1-0.1 mm), silt $(0.1-0.01 \mathrm{~mm})$ and clay $(<0.01 \mathrm{~mm})$ fractions.

The SPM content was obtained by filtration through membrane filters with pore diameter of $0.47 \mu \mathrm{m}$ followed by gravimetry. The particulate OC (POC) composition was analyzed on samples filtered on pre-combusted $\left(12 \mathrm{~h}, 450{ }^{\circ} \mathrm{C}\right)$ glass fiber filters (GF/F $0.7 \mu \mathrm{m}$, Whatman) of $47 \mathrm{~mm}$ or $142 \mathrm{~mm}$ diameters, respectively, which were upon filtration immediately transferred to pre-combusted aluminum envelopes, frozen and kept at $-18^{\circ} \mathrm{C}$ until analysis.

Surface sediment samples were retrieved with a Van Veen grab sampler. The topmost surface sediment layer was trans- ferred with stainless steel spatulas to pre-cleaned polyethylene containers before being stored at $-18^{\circ} \mathrm{C}$ until analysis.

Elementary $\mathrm{OC}$ and isotopic $\left(\delta^{13} \mathrm{C}\right)$ composition of bottom sediment were determined by Carlo Erba elemental analyzers and a Finnigan MAT Delta Plus mass spectrometer, respectively, at the International Arctic Research Center, University of Alaska, Fairbanks (USA) and with similar instruments at Stockholm University (Sweden). Accuracy and reproducibility of the isotope results were within $\delta^{13} \mathrm{C} \pm 0.1 \%$. Freeze dried sediment for each station were weighed into pre-combusted silver capsules $(5 \times 9 \mathrm{~mm}$, Säntis Analytical AG, Teufen, Switzerland) and acidified in situ with $50 \mu \mathrm{l} 1 \mathrm{M}$ $\mathrm{HCl}$ for removal of carbonates, and dried over night in $60^{\circ} \mathrm{C}$ following procedure adapted from Gustafsson et al (1997). A similar procedure of in situ acidification and subsequent drying in silver capsules $(5 \times 12 \mathrm{~mm})$ were followed for POC on sub-sampled GF/F filters (8-12 punches of $5 \mathrm{~mm}$ ). Acidified samples were analyzed in triplicates for organic carbon content and its $\delta^{13} \mathrm{C}$ composition using isotope ratio mass spectrometer.

Study of the thermohaline structure of the water column was performed using a Conductivity-Temperature-Depth (CTD) sensor package (SeaBird 19Plus). The character of the vertical structure was evaluated by the Hanssen-Rattray $(\Delta S)$ parameter determined as a function of the salinity deviation at the bottom and at the surface to the average vertical deviation (Hansen et al., 1966).

\section{Results and discussion}

\subsection{Sediment material transport and distribution in connection with specific hydrometeorological conditions.}

\subsubsection{August 2005 survey}

The Lena River 2005 discharge was one of the lowest (annual discharge was $617 \mathrm{~km}^{3}$ ) for the period 1999-2008, but significantly above about average long-term (1937-1986) data $\left(511 \mathrm{~km}^{3}\right)$ (Antonov, 1987) (Table 1) and the August survey period coincided with the minimal summertime river water level. South and south-easterly winds with average velocity of $11-12 \mathrm{~m} \mathrm{~s}^{-1}$ prevailed in the Buor-Khaya Gulf. During such windy conditions, the water column in the area 

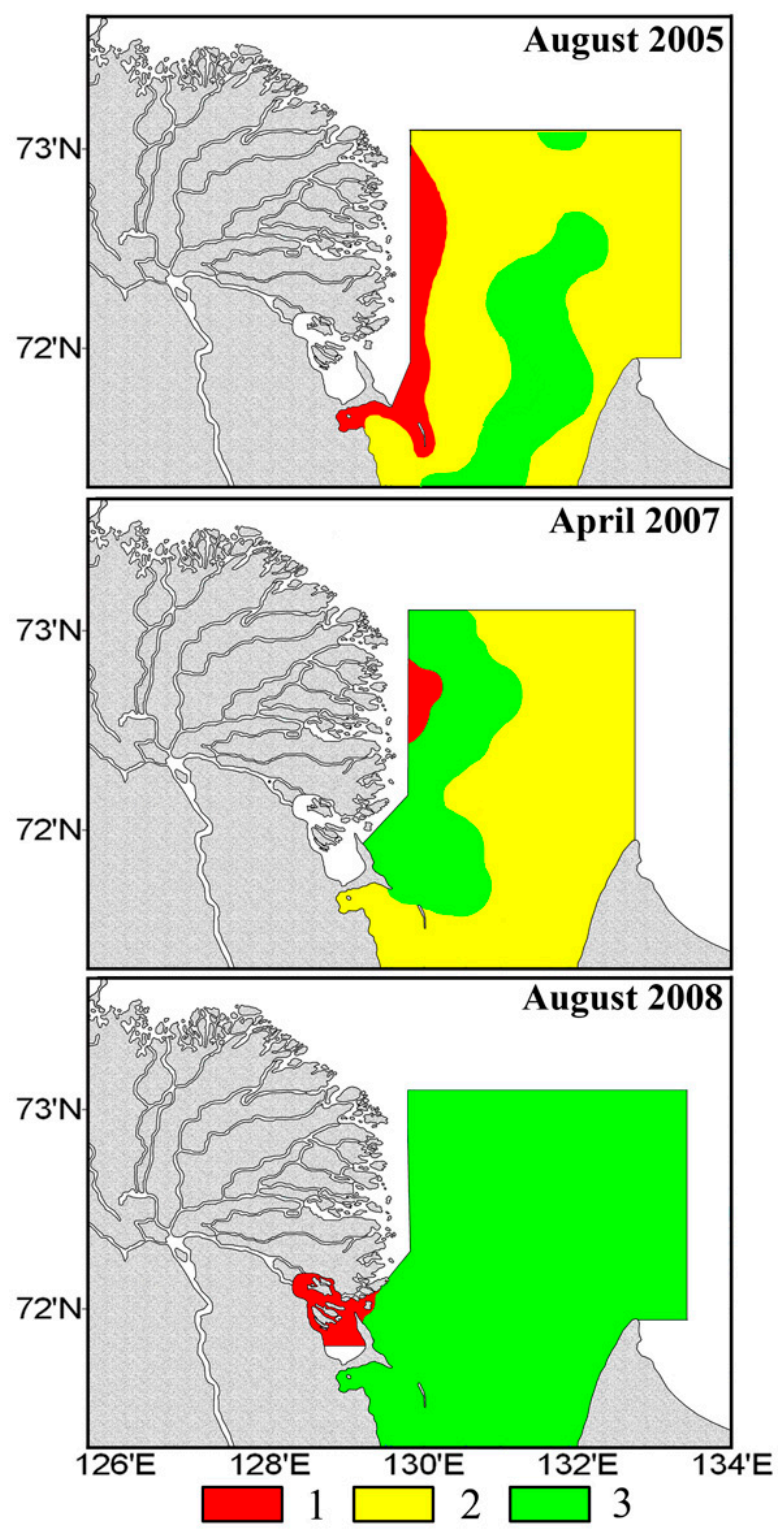

Fig. 2. Stratification of water column of the Buor-Khaya Gulf according to Hanssen-Rattri index: 1 - intermixed waters, 2 medium-stratified, 3 - stratified.

adjacent to the Lena Delta was mixed down to the bottom (depth of $\sim 8 \mathrm{~m}$ ) (Figs. 2, 3). However, for most of the BuorKhaya Gulf, the water column remained moderately stratified (Fig. 2). Salinity varied from $4.9-12.1 \%$ in the surface layer and up to $8.9-31.5 \%$ in the bottom layer (Table 2, Fig. 3). The surface water temperature varied from $3.5^{\circ} \mathrm{C}$ in the northeast of the Gulf up to $5.5^{\circ} \mathrm{C}$ along the marine margin of the delta with corresponding bottom water temperatures of $5^{\circ} \mathrm{C}$ and $0.9^{\circ} \mathrm{C}$, respectively (Table 3 ).

Storm surge onto the continental coast creates favorable conditions for intense coastal erosion. As a result of bottom sediment resuspension, SPM in the near-bottom water layer

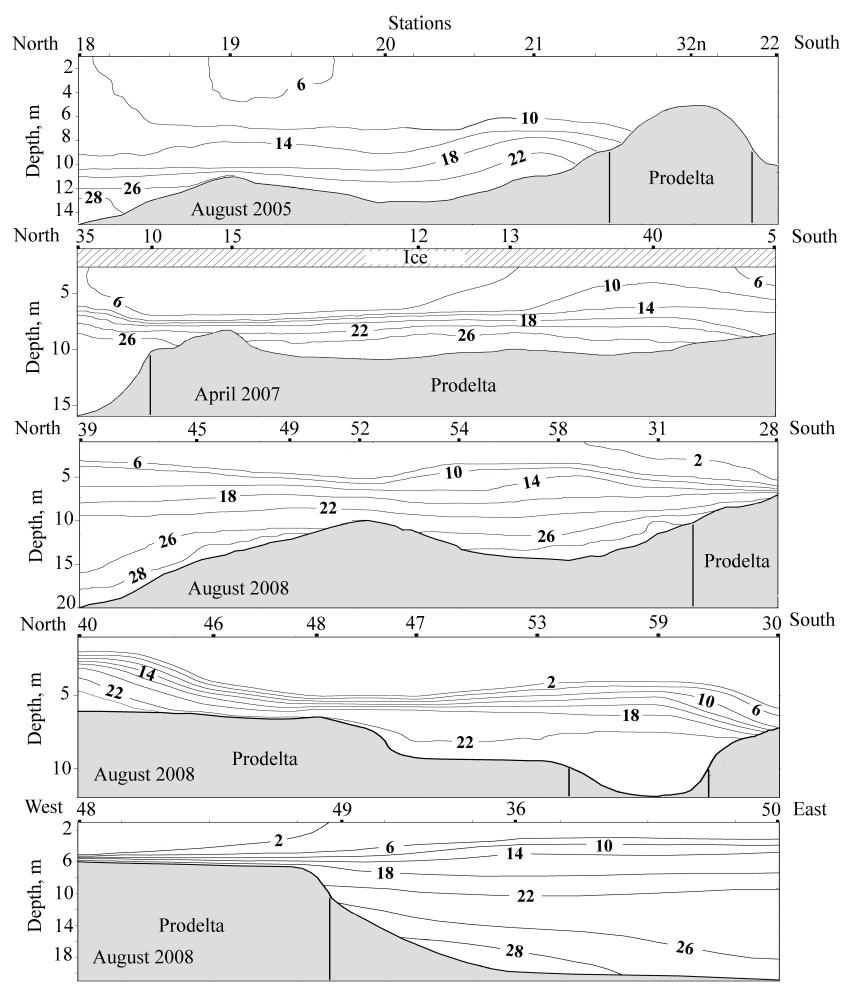

Fig. 3. Vertical sections of salinity (\%o) distribution for years 2005 , 2007 and 2008.

reached $187 \mathrm{mg}^{-1}$ (average $57.9 \mathrm{mg}^{-1}$ ) (Table 2), which is possible when the critical shear stress $(P)$ of the bottom sediments is exceeded (Beach et al., 1992). According to this criteria, when the Beach-Sternberg $P$ value is $0.8<P<2.5$ and the dynamic flow velocity $u_{*}$ is about $25 \mathrm{~cm} \mathrm{~s}^{-1}$, sedimentary material can be resuspended and transported in the Buor-Khaya Gulf as SPM.

The $P$ value is calculated as a function of wet density $\left(w_{s}\right)$ divided by the product of $u_{*}$ and the unit less Karman constant $k=0.4$ (Beach et al., 1992).

$P=w_{s} / k u_{*}$

The following initial parameters were used: average particle wet density of $1.55-1.75 \mathrm{~g} \mathrm{~cm}^{-3}$, actual current rates during the ice-free period of 10, 25, 50 and $100 \mathrm{~cm} \mathrm{~s}^{-1}$ (Voinov, 1994, Navigational book, 1998). Under normal (non-stormy) conditions $\left(u_{*} \approx 10 \mathrm{~cm} \mathrm{~s}^{-1}\right)$ the main type of particle transportation thus occurs in SPM $(P<0.6)$. The SPM values did not exceed $45 \mathrm{mg}^{-1}$ (average 17.5) in the surface water layer (Figs. 4, 5, Table 3). SPM concentrations in the Lena tidal flat area located close to the intensively degrading northern coast of Muostakh Island were up to $594 \mathrm{mg} \mathrm{l}^{-1}$.

POC content in the surface water varied from $0.13 \mathrm{mg} \mathrm{l}^{-1}$ (northeast Buor-Khaya Gulf) up to $1.7-2.0 \mathrm{mgl}^{-1}$ (Muostakh Island region) (Fig. 6). Maximum POC content in bottom waters exceeded $2.0 \mathrm{mgl}^{-1}$ and was observed in 
Table 2. Amounts of executed works and analytical researches of suspended particulate matter, bottom and coastal sediments samples.

\begin{tabular}{|c|c|c|c|c|c|c|}
\hline \multirow{2}{*}{$\begin{array}{l}\text { Versions of investigations } \\
\text { and analytics }\end{array}$} & \multicolumn{5}{|c|}{ Year of supervision and volumes of investigations } & \multirow[t]{2}{*}{ Total } \\
\hline & $\begin{array}{c}2000 \\
\text { August- } \\
\text { September }\end{array}$ & $\begin{array}{c}2005 \\
\text { August- } \\
\text { September }\end{array}$ & $\begin{array}{c}2006 \\
\text { August- } \\
\text { September }\end{array}$ & $\begin{array}{c}2007 \\
\text { March- } \\
\text { April }\end{array}$ & $\begin{array}{c}2008 \\
\text { August- } \\
\text { September }\end{array}$ & \\
\hline \multicolumn{7}{|l|}{ Bottom sediments } \\
\hline Sampling (POI) & 23 & 74 & 26 & 53 & 56 & 232 \\
\hline Grain size (POI) & 23 & 74 & 14 & 53 & 20 & 184 \\
\hline OC (IARC, ITM) & 23 & 44 & - & 53 & 36 & 156 \\
\hline$\delta^{13} \mathrm{C}(\mathrm{IARC}, \mathrm{ITM})$ & 23 & 44 & - & 53 & 36 & 156 \\
\hline \multicolumn{7}{|l|}{ Coastal zone sediments } \\
\hline Sampling of coastal zone sediments (POI) & - & 21 & 28 & 5 & 18 & 72 \\
\hline OC of coastal zone sediments (IARC, ITM) & - & 21 & 28 & - & 9 & 58 \\
\hline$\delta^{13} \mathrm{C}$ of coastal zone sediments (IARC, ITM) & - & 21 & 28 & - & 9 & 58 \\
\hline \multicolumn{7}{|l|}{ Suspended particulate matter } \\
\hline Sampling (POI) & 92 & 148 & 52 & 78 & 112 & 482 \\
\hline Concentration (POI) & 92 & 148 & 52 & 78 & 112 & 482 \\
\hline POC (IARC, ITM) & - & 114 & - & 36 & 16 & 166 \\
\hline$\delta^{13} \mathrm{C}$ (IARC, ITM) & - & 114 & - & 36 & 16 & 166 \\
\hline
\end{tabular}

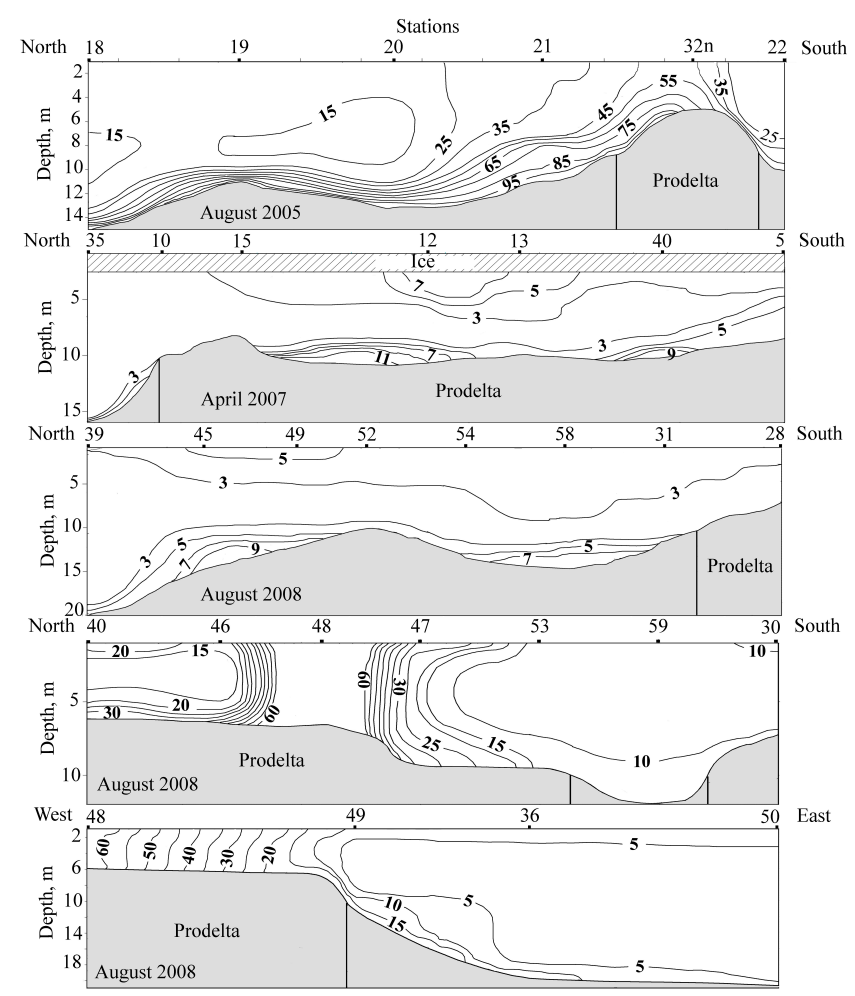

Fig. 4. Vertical sections of $\mathrm{SPM}\left(\mathrm{mg}^{-1}\right)$ distribution for years 2005, 2007 and 2008. the nepheloid layer (Fig. 3), shallow waters around $\mathrm{Mu}$ ostakh Island, sediments underlying deeper waters and near the prodelta. The OC content in bottom sediments varied from $1 \%$ along the estuary sea line and Buor-Khaya Gulf up to $4 \%$ along the delta front, and in sediments underlying deeper waters (Fig. 6). Spatial variability of the OC content in bottom sediments follows the sediment size distribution (Figs. 6, 7, 8).

The $\delta^{13} \mathrm{C}$-POC values in the surface water varied from $-28.5 \%$ to $-26.4 \%$ (Fig. 9). In bottom sediments the values varied from $-22.9 \%$ near Muostakh Island to $-26.3 \%$ within the prodelta. As a whole, sediment fields with $\delta^{13} \mathrm{C}$ lighter than $-25 \%$ prevailed (Fig. 9).

\subsubsection{April 2007 survey}

When the Buor-Khaya Gulf is ice covered, the Lena River influence (despite low discharge in winter) is reflected in water column stratification in the western part of the Gulf (Fig. 2). In the prodelta, salinity varied from $0.16-7.2 \%$ in the under-ice surface water to $0.7-23 \%$ (Fig. 3) in the bottom waters, while at greater distances from the delta the salinities increased to $13.9-15.4 \%$ in the surface layer and $25.2-27.4 \%$ in the bottom waters. Water temperatures were near-freezing everywhere except near outlets of the Lena channels where the Lena River heating effect is significant even in winter (Table 3).

The SPM content in April 2007 was low due to halted coastal erosion processes and low river flow. Maximum values of $11.8 \mathrm{mg} \mathrm{l}^{-1}$ at the surface and $15.2 \mathrm{mg} \mathrm{l}^{-1}$ 
Table 3. Temporal variability of core hydrological and sedimentation parameters for water column and bottom sediments under different types of sedimentation regime.

\begin{tabular}{|c|c|c|c|c|c|c|c|}
\hline \multicolumn{2}{|c|}{ Parameters } & \multicolumn{2}{|c|}{ Type I } & \multicolumn{4}{|c|}{ Type II } \\
\hline & & \multicolumn{2}{|c|}{ August 2005} & \multicolumn{2}{|c|}{ April 2007} & \multicolumn{2}{|c|}{ August 2008} \\
\hline & & Surface & Bottom & Surface & Bottom & Surface & Bottom \\
\hline \multirow[t]{3}{*}{ Salinity, \%o } & average & 8.7 & 24.1 & 6.3 & 19.6 & 2.4 & 25.8 \\
\hline & $\max$ & 12.1 & 31.5 & 15.4 & 27.4 & 8.4 & 28.9 \\
\hline & $\min$ & 4.9 & 8.9 & 0.24 & 0.7 & 0.1 & 9.3 \\
\hline \multirow[t]{3}{*}{ Temperature, ${ }^{\circ} \mathrm{C}$} & average & 4.4 & 1.1 & 0.06 & -0.32 & 10.1 & -0.43 \\
\hline & $\max$ & 5.5 & 5.0 & 2.3 & 0.15 & 16.5 & 7.5 \\
\hline & $\min$ & 3.5 & -0.9 & -0.48 & -0.7 & 5.2 & -1.37 \\
\hline \multirow[t]{3}{*}{$\mathrm{SPM}, \mathrm{mg} \mathrm{l}^{-1}$} & average & 17.5 & 57.9 & 2.9 & 4.8 & 11.2 & 13.4 \\
\hline & $\max$ & 45 & 186 & 11 & 15.2 & 64 & 64.6 \\
\hline & $\min$ & 2.5 & 5.1 & 1.2 & 1.5 & 1.9 & 3.2 \\
\hline \multirow[t]{3}{*}{$\mathrm{POC}, \mathrm{mg} \mathrm{l}^{-1}$} & average & 0.6 & - & 0.07 & - & 0.5 & - \\
\hline & $\max$ & 2.0 & - & 0.10 & - & 1.1 & - \\
\hline & $\min$ & 0.13 & - & 0.03 & - & 0.24 & - \\
\hline \multirow[t]{3}{*}{$\delta^{13} \mathrm{C}-\mathrm{POC}$} & average & -27.1 & - & -27.6 & - & -28.6 & - \\
\hline & $\max$ & -26.4 & - & -23.6 & - & -24.3 & - \\
\hline & $\min$ & -28.2 & - & -29.9 & - & -32.2 & - \\
\hline \multirow[t]{3}{*}{ SOC, $\%$} & average & 2.9 & - & 3.7 & - & 2.05 & - \\
\hline & $\max$ & 4.2 & - & 9.0 & - & 6.0 & - \\
\hline & $\min$ & 1.4 & - & 0.20 & - & 0.40 & - \\
\hline \multirow[t]{3}{*}{$\delta^{13} \mathrm{C}-\mathrm{SOC}$} & average & -25.9 & - & -25.6 & - & -25.8 & - \\
\hline & $\max$ & -22.9 & - & -22.6 & - & -25.3 & - \\
\hline & $\min$ & -26.5 & - & -26.4 & - & -26.6 & - \\
\hline
\end{tabular}

at the bottom were detected at the Bykovskaya channel mouth. The average SPM values were $2.9 \mathrm{mgl}^{-1}$ for under-ice surface waters and $4.8 \mathrm{mg}^{-1}$ in the bottom layer (Figs. 4, 5, Table 3).

The POC content was also low and did not exceed $0.1 \mathrm{mgl}^{-1}$. Maximum values were detected in front of the channel outlets and north of the prodelta. Fluvial sources of POC is indicated by $\delta^{13} \mathrm{C}$ values hovering about $-29 \%$. A POC hot spot with $\delta^{13} \mathrm{C}$ values of $-23.6 \%$ was detected opposite of the Bykovskaya channel mouth.

The OC concentration in the prodelta surface sediments varied from $2.5-9.2 \%$, which is higher than summer conditions (Fig. 6). The $\delta^{13} \mathrm{C}-\mathrm{OC}$ in surface sediments generally varies within the range from -25 to $-27 \%$ except for the eastern continental-oriented slope of the Muostakh Island where the isotopic signature is unusually heavy for this area: $-22.6 \%$ (Fig. 9).

\subsubsection{August 2008 survey}

The discharge of the Lena River was abnormally high in 2008 (annual discharge $716 \mathrm{~km}^{3}$ ). This influenced the salinity, temperature and water column stratification throughout the Buor-Khaya Gulf. Similar to 2005 our survey was performed during the low-water period. Gentle south and southeast winds $\left(1-2 \mathrm{~m} \mathrm{~s}^{-1}\right)$ prevailed in the Buor-Khaya Gulf during this survey period. The low winds and large freshwater discharge created a strongly stratified water column throughout the Buor-Khaya Gulf all the way to the $4 \mathrm{~m}$ isobath outside the Lena River Delta (Figs. 2, 3). Salinity varied from $0.1 \% \circ$ at the surface to $24.5 \% \circ$ at the bottom, and temperature varied from $16.2^{\circ} \mathrm{C}$ to $2.6^{\circ} \mathrm{C}$, respectively (Fig. 3, Table 3). Moving east to the deeper parts of the Buor-Khaya Gulf the salinity was $2.6 \%$ and temperature $14.1{ }^{\circ} \mathrm{C}$ in the surface layer while the near-bottom waters had a salinity of $28.9 \%$ and temperature below zero $\left(-1.3^{\circ} \mathrm{C}\right)$. The prevailing hydrometeorological conditions thus caused a welldefined Lena River freshwater lense throughout the Gulf. The poor vertical mixing caused most of Buor-Khaya Gulf to keep remnant winter bottom water characteristics with low temperature $\left(0.4^{\circ} \mathrm{C}\right.$ to $\left.1.37^{\circ} \mathrm{C}\right)$ and high salinity (24.7 to $28.9 \%$ ), respectively (Fig. 3, Table 3).

The 2008 SPM values in the Buor-Khaya Gulf surface waters spanned 2.1-64.2 $\mathrm{mgl}^{-1}$ (average 11.2 $\mathrm{mgl}^{-1}$ ), and in the bottom waters $3.2-64.6 \mathrm{mg} \mathrm{l}^{-1}$ (average $13.4 \mathrm{mg} \mathrm{l}^{-1}$ ). 


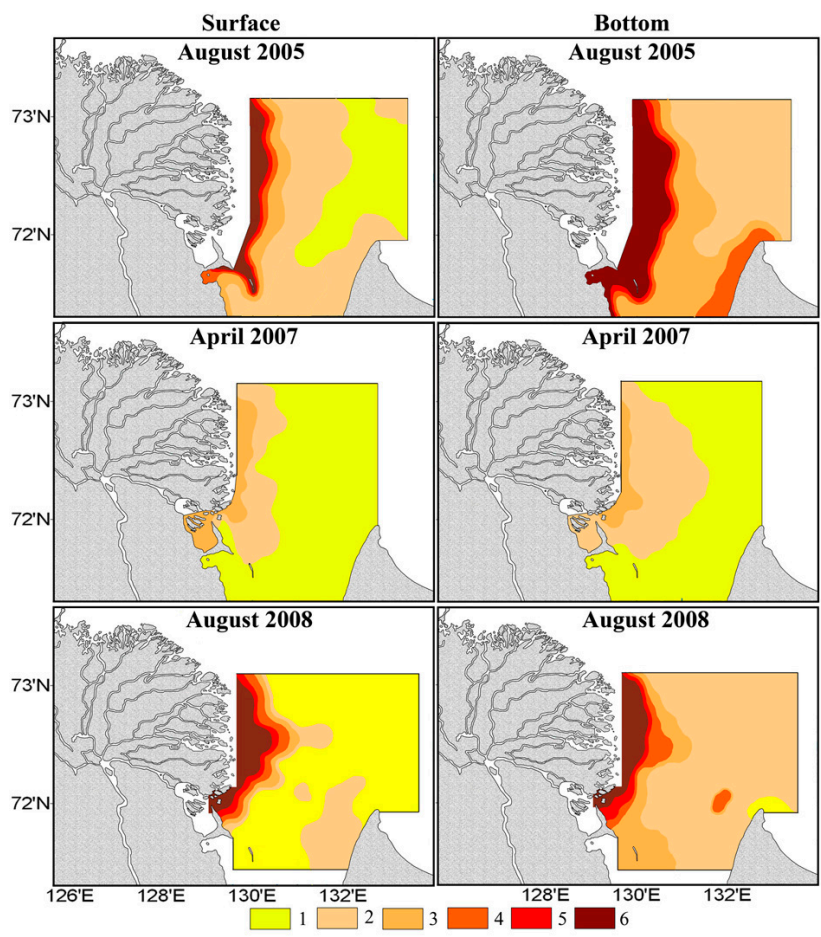

Fig. 5. Distribution of SPM $\left(\mathrm{mg}^{-1}\right)$.

The maximum values were detected in the river plume outside the mouth of Sardakhsko-Trofimovskaya channels (Figs. 4, 5). The August-2008 SPM loadings were low relative to August-2005, which is more representative of general conditions in the multi-year observations. The 2008 SPM values were 1.5 times lower in the surface layer and four times lower in the bottom water layer (Table 3 ).

The POC content in the surface water layer of the BuorKhaya Gulf varied from $0.24-1.1 \mathrm{mg}^{-1}$ with the maximum values detected in the river plume outside to the mouth of Sardakhsko-Trofimovskaya channels. The POC- $\delta^{13} \mathrm{C}$ in the surface water layer varied from $-26.4 \%$ near the river mouth to -29 to $-32 \%$ in the offshore part of the BuorKhaya Gulf (Fig. 9). These highly depleted POC- $\delta^{1} 3 \mathrm{C}$ has been suggested to reflect a contribution from primary production based on pre-depleted terrestrial DIC- $\delta^{13} \mathrm{C}$ (SánchezGarcía et al., 2011).

Maximum OC content in surface sediments was also found near the mouth of the Sardakhsko-Trofimovskaya channels. OC values decreased eastward from $6 \%$ to $1-2 \%$ in the central part of the Buor-Khaya Gulf (Fig. 6). As in previous years, lowest $\mathrm{OC}$ values were detected in the northeastern corner of the Buor-Khaya Gulf study polygon (Fig. 6). The $\delta^{13} \mathrm{C}$-OC of the surface sediments was similar in 2008 to that of 2005. This may either reflect that the relative source contributions were similar and just experiencing different extents of dilution or that the $\delta^{13} \mathrm{C}$ signals are not well separated between the river and erosion end members. This latter has
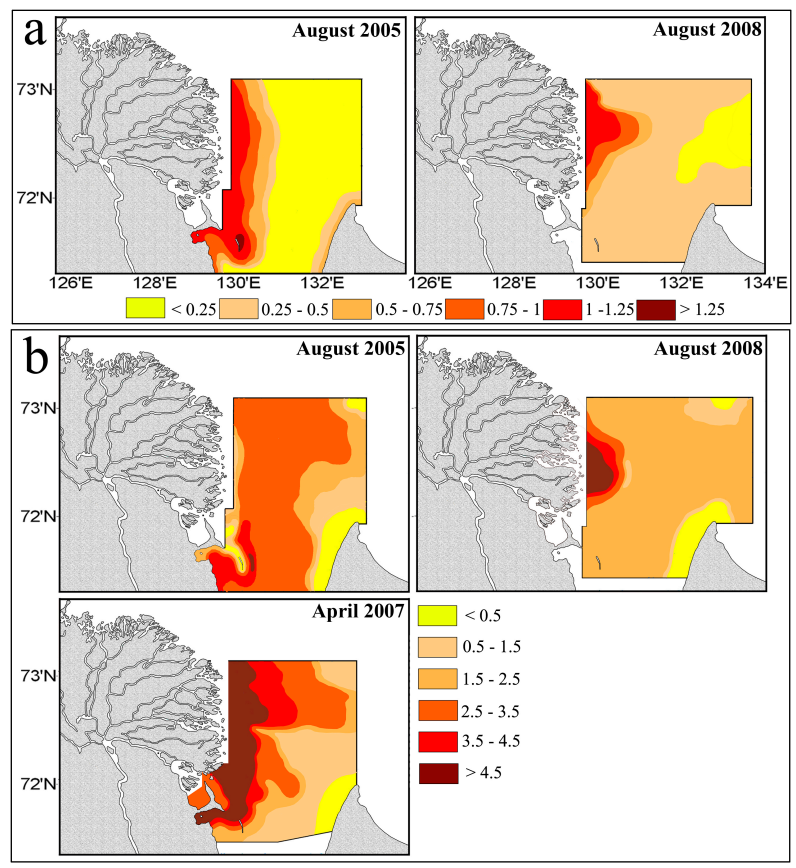

Fig. 6. OC content of (a) water column (POC, $\mathrm{mg}^{-1}$ ) and (b) bottom sediments $(\%)$.

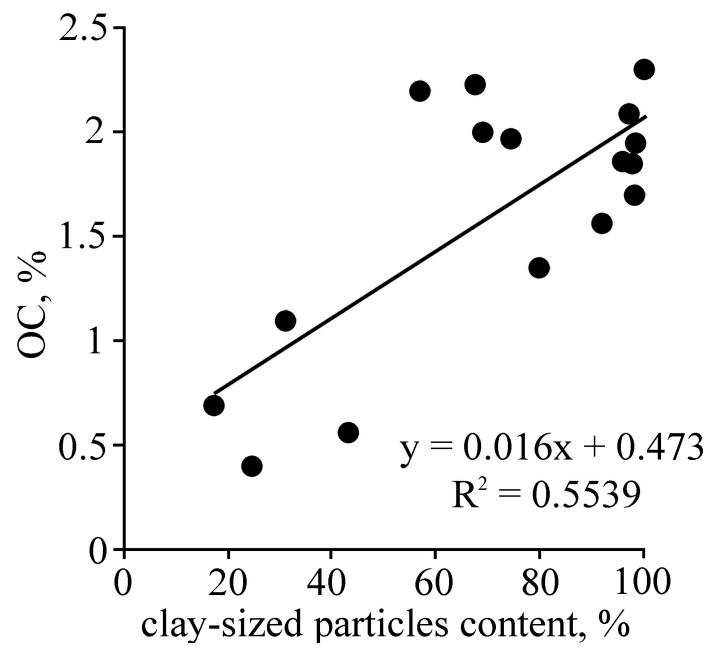

Fig. 7. Correlations between clay-sized particles content $(\%)$ and OC content in bottom sediments (\%) for year 2005.

recently been suggested (e.g. Vonk et al., 2010a) and the distinction between the two may be more approachable with $\Delta^{14} \mathrm{C}$ measurements (e.g., Vonk et al., 2010b; Karlsson et al., 2011; Gustafsson et al., 2011). 


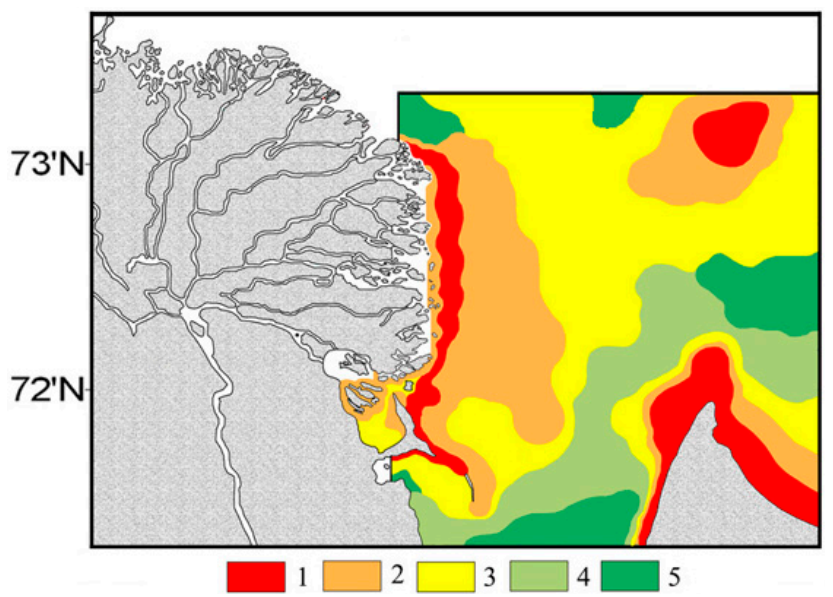

Fig. 8. Types of bottom sediments: 1 - sand, 2 - silty sand, $3-$ clayey silt, 4 - silty clay, 5 - clay.

\subsection{Two different regimes for particle delivery and sedimentation}

Two types of sedimentation regimes were defined on the basis of the obtained results: Type I erosion-accumulation (summers of 2000, 2005-2007) and Type II accumulation (winter periods, summer of 2008). These two regimes are schematically and photographically visualized in Fig. 10. The sedimentation dynamics are determined by complex interaction between the hydrometeorological conditions, river discharge, and sea-ice regime in the Lena River Delta and in the recipient Buor-Khaya Gulf. Below we describe these two dominant sedimentation regimes based on the most detailed years of observations taken in summers (August 2005 and 2008) and winter (April 2007).

\subsubsection{Sedimentation regime: Erosion-accumulation (Type I)}

The erosion-accumulation sedimentation regime is characterized by hydrometeorological processes such as storm surges and strong currents. This regime was studied in detail in August 2005 and also observed in the summer periods of years 1999, 2000, 2006 and 2007 (data not shown). Most of these summer period surveys in the Buor-Khaya Gulf were executed during or right after severe storms. Such conditions are of high repeatability (40-50 times a year) and long duration (up to 11 days) and therefore are typical for these waters during the ice-free period (Navigation book of the Laptev Sea, 1998).

The prevailing strong winds in the Gulf result in considerable storm surges on the Gulf coastline (Navigation book of the Laptev Sea, 1998). Hence, this creates favorable conditions for erosion of both the coastal ice-complex and of the bottom sediments, resulting in elevated SPM levels (Figs. 4, 5). As noted above, conditions for bottom sediment ero-

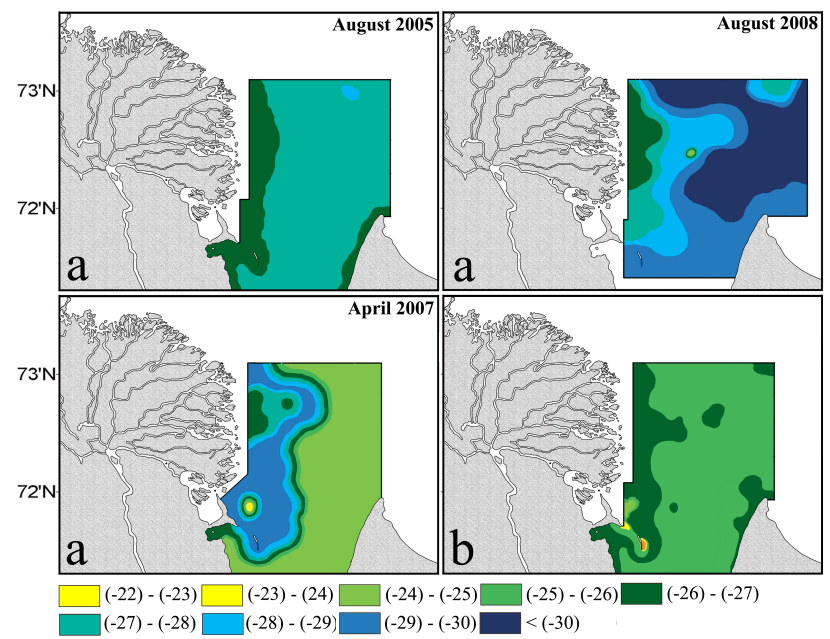

Fig. 9. Distribution of $\delta^{13} \mathrm{C}(\%$ ) in water column (a) and bottom sediments (b), combined 2000, 2005, 2007 and 2008 years.

sion/resuspension are possible when the near-bottom shear stress exceeds the critical sheer stress value (Beach et al., 1992). If the dynamic flow velocity is $25 \mathrm{~cm} \mathrm{~s}^{-1}$ or higher, less cohesive bottom sediments can simultaneously be transported both as water column SPM and in the bottom nepheloid layer. At first only fine particles such as low-density organic and organo-mineral aggregates/flocculates are remobilized. As the flow velocity grows, heavier mineral particles become part of the SPM (Beach et al., 1992; Longinov, 1973) (Figs. 4, 5, 10). Consistent with these hydrodynamic expectations maximum SPM content in summer of 2005 was found in the Lena River prodelta at depths less than 8 meters (Figs. 4, 5). As under the storm conditions ascending and descending vectors of turbulent exchange are mutually balanced (Bowden, 1983; Longinov, 1973; Leontyev, 2001), the SPM content is vertically well-mixed throughout the water column. The bottom water nepheloid layer is distinctly marked by the stratification, salinity, temperature and SPM (Figs. 2, 3, 4, 5). Further offshore, the intensity of these hydrodynamic processes is weakened, which is reflected in stratification of the water column and its SPM content. The SPM content decreased by $10-15$ times over the abrasion-accumulation plain in the central part of the well-stratified Buor-Khaya Gulf compared with in the shallow waters (Figs. 1, 2, 3, 4, 5 and 10). Salinity increased here twofold and near-bottom temperatures decreased down to negative values.

With a wave height $(H)$ in the Buor-Khaya Gulf of 2.5 $3.0 \mathrm{~m}$ and a depth of $25-30 \mathrm{~m}$, the algorithm: $h_{\text {crit }}=10 \mathrm{H}$ (Longinov, 1973) suggests that the direct wave impact zone may potentially be distributed over the whole Gulf. However, durability of such strong waves is short and the wave height in the Buor-Khaya Gulf usually does not exceed $1 \mathrm{~m}$ (Table 4). This results in bottom erosion having the greatest 
Table 4. The average frequency of wave heights for Buor-Khaya Bay (Navigational book, 1998).

\begin{tabular}{lccccc}
\hline $\begin{array}{l}\text { Wave } \\
\text { height, } \mathrm{m}\end{array}$ & July & $\begin{array}{c}\text { Average frequency, } \% \\
\text { August }\end{array}$ & $\begin{array}{c}\text { September } \\
\text { October }\end{array}$ & $\begin{array}{c}\text { Average for ice-free } \\
\text { period, } \%\end{array}$ \\
\hline$<1$ & 70 & 63 & 61 & 58 & 63 \\
$1-2$ & 22 & 21 & 20 & 23 & 22 \\
$2-3$ & 6 & 11 & 13 & 15 & 11 \\
$3-5$ & 2 & 5 & 6 & 4 & 4 \\
\hline
\end{tabular}

impact at depths less than $10 \mathrm{~m}$ (Navigation book of the Laptev Sea, 1998). This prediction is consistent with observations of coarse fractions of bottom sediments at these shallow depths (Fig. 8).

In this Type I sedimentation regime (erosionaccumulation), thermal and wave/wind abrasion of the coastal ice-complex is activated, resulting in large volumes of terrigenous material being remobilized into coastal waters (Figs. 4, 5, 10). In the Laptev Sea, the annual supply of sedimentary material by coastal erosion is estimated to $58.4 \times 10^{6} \mathrm{tyr}^{-1}$ (Stein, et al., 2004) (Table 2). During the last 300 years under the thermal abrasion influence in the East Siberian Arctic, several islands in the Laptev Sea have disappeared under the water surface (Zemlya Sannikova, Figurina, Vasilyevskiy Island, Semyonovskiy Island) (Dudarev et al., 2006a; Are, 1985). In addition to these well-known and named islands, the northeastern part of the Buor-Khaya Gulf is characterized by subsea relicts of past islands (Fig. 1). These subsea features have lithogenic characteristics (i.e. sand) that are consistent with recent (bottom) erosion of these island relicts rather than by hydrodynamically transported/sorted sedimentation (compare northeastern study region in Figs. 1 and 8).

Muostakh Island, located in the western Buor-Khaya Gulf, is composed of the Pleistocene ice-complex and has been studied by many investigators since the 1950s (e.g. Are, 1985; Grigoryev and Kunitsky, 2000). Over the course of the last 50 years, Muostakh Island has retreated strongly with a total erosion up to $700 \mathrm{~m}$ at the Northern Cape and average erosion rates of $14 \mathrm{~m} \mathrm{yr}^{-1}$. At the same time, the island width has decreased by $250-300 \mathrm{~m}$ at an average rate of 5-6 $\mathrm{m} \mathrm{yr}^{-1}$ (Grigoryev and Kunitsky, 2000). Assuming that the width of the southern edge of the Bykovskiy Peninsula $(1.3 \mathrm{~km})$ and the current northern edge of Muostakh Island were similar at the time of their separation about $1.5-3 \mathrm{kyr}$ ago, the millennium-scale average rate of island width decrease after separation is much lower and estimated to be only $0.3-$ $0.5 \mathrm{~m} \mathrm{yr}^{-1}$. Apparently, the rate of erosion of Muostakh Island is much higher in recent decades than the average over the past few thousand years (Charkin et al., 2009).

Under the erosion-accumulation sedimentation (Type I) in the Buor-Khaya Gulf, the distribution of SPM, salinity, temperature and thus water column stratification is consistent

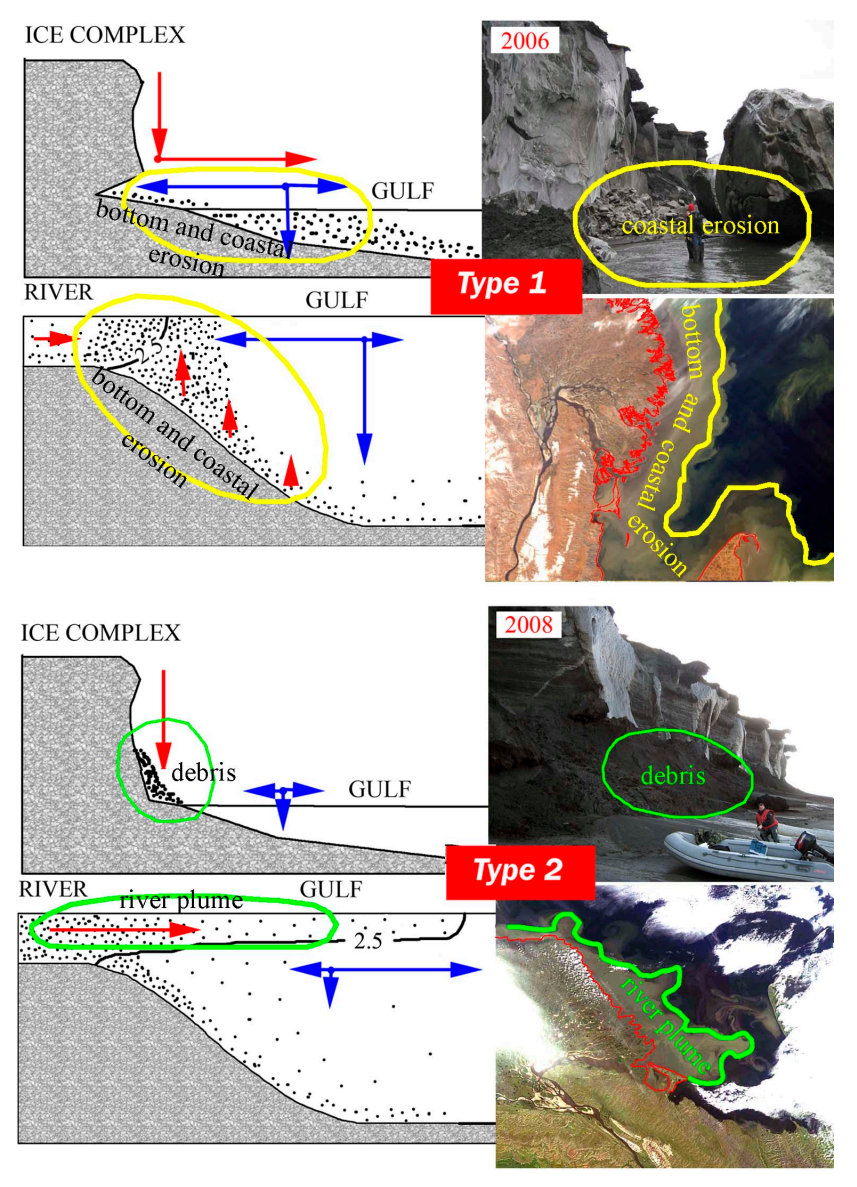

Fig. 10. Delivery scheme of sedimentary material from coastal icecomplex and mouths of the Lena River flow channels for two sedimentation regimes. Black points show concentration of sedimentary material, blue arrows show force and direction of movement of water, red arrows show intensity and direction of movement of flows of sedimentary material. Picture snapshots show northern coast of Muostakh Island at different sedimentation regimes. Satellite snapshots feature flows of SPM under various regimes of sedimentation.

with the distribution of the properties in the underlying bottom sediments and subwater reliefs (Figs. 1, 2, 3, 4, 5 and 10). Size composition of bottom sediments is represented by sequential facies substitution in the direction from the delta to the central part of the Gulf with sands in the delta, silty 

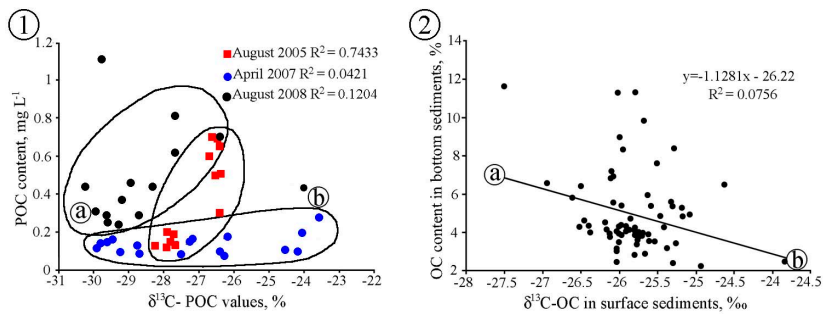

Fig. 11. $\delta^{13} \mathrm{C}$ values of POC (1) and surface sediments (2) vs. POC concentrations (1) $\left(\mathrm{mgl}^{-1}\right)$ and $\mathrm{OC}$ content in surface sediment (2) $(\%)$. The linear correlations suggest mixing between two endmembers hypothesized to be allochthonous (a) and autochthonous (b).

sediments in the prodelta and clays making up the alluvial fan of the Lena River. Fine sediments also accumulate in the central part of deep erosion channels that extend several kilometers beyond the marine margin of the delta. Sedimentation of sands and coarse silts particles are thus reflected in the formation of the lithological pattern of the delta and prodelta. The regime of the prodelta foot (beyond the $5-10 \mathrm{~m}$ isobath) is characterized by silty sediments. At depths $>10 \mathrm{~m}$, the alluvial fan is formed. The surface of the accumulation-abrasion plane of the Gulf's deep-water part consists of clayey silt and silty clay sediments (Fig. 8). The structure of the SPM distribution and the hydrological characteristics coincides with the distribution of the bottom sediment structure and bottom reliefs, supporting the fact that the sedimentation type I (erosion-accumulation) is the predominant mode for the icefree summer period in the Buor-Khaya Gulf.

\subsubsection{Sedimentation regime: Accumulation (Type II)}

This accumulation-only type of sedimentation regime stably develops under ice-covered conditions, and in conditions of limited turbulent vertical mixing and absence of storm surges (i.e. long periods of low winds/waves). We found this type II of sedimentation in April 2007 and in August 2008.

The Buor-Khaya Gulf freezes up in mid-October. Depending on the volume of annual continental runoff, the thickness of fast ice varies between 1.9-2.4 $\mathrm{m}$ with its maximum in April. Once ice covered, the contribution from coastal erosion is decreasing, fluvial input is decreasing from "small" to "negligible" values of PM and POC, and all the material from the water column has accumulated because no (or very little) resuspension or lateral (nepheloid) transport is occurring. Thus, the SPM content in the prodelta water column in winter was reduced 5-10 times (down to $5-10 \mathrm{mg}^{-1}$ ) in comparison with the summer period (Figs. 4, 5). In winter, the hydraulic velocity and the overall river discharge are low. In comparison with the summer period the SPM content in the mouth of the Bykovskiy channel is reduced by 2-3 times (down to $11 \mathrm{mg}^{-1}$ ), and in the mouth of the Sardakhskaya channel more than 6 times (down to $9 \mathrm{mg}^{-1}$ ) (Figs. 4, 5).
With low discharge and absence of vertical wind-induced mixing, interaction between river water and seawater cause a stable frontal zone (Figs. 2). Superimposed on this feature are two well-defined freshwater plumes outside the mouths of the Bykovskiy and the Sardakhsko-Trofimovskaya delta channels affecting the distribution of many parameters (Figs. 2, 3, 4, 5, 6). Freshwater discharge from these channels reduces surface water salinities to below 6 in the adjacent stretches of shallow water $(<10 \mathrm{~m}$ deep) (Figs. 2, 3) (see also Eicken et al., 2005). Taken together, winter conditions are characterized by absence of measurable erosion and resuspension and low sedimentation-accumulation of riverine sediments.

August 2008 experienced an anomalous hydrometeorological situation with almost no winds and the highest Lena River discharge of our 1999-2008 study period. This resulted in a unique hydrological situation with strong stratification, a pycnocline as shallow as $4 \mathrm{~m}$, with steep vertical gradients of temperature and salinity of $4{ }^{\circ} \mathrm{C} \mathrm{m}^{-1}$ and $7 \% \mathrm{~m}^{-1}$, respectively (Fig. 3). The average salinity in the surface layer was 3.5 times lower than for same month in 2005 , while the temperature was twice as high $\left(4.4^{\circ} \mathrm{C}\right.$ in 2005 and $10^{\circ} \mathrm{C}$ in 2008) (Table 2). The calm weather during the ice-free period leads to formation of Type II sedimentation processes, which otherwise is normally observed only under winter conditions (Fig. 10).

The so-called backwater zone (i.e. countercurrents induced by high tides) plays an important lithodynamic role and represents a hydrodynamic sediment barrier for removal of part of the river SPM from transit to the ocean (Dudarev et al., 2006b). It is illustrated by the SPM distribution. The SPM content in the surface layer at the marine margin of the prodelta decreased from $64 \mathrm{mgl}^{-1}$ to $3 \mathrm{mg}^{-1}$ (Figs. 4, 5). At first, the coarse-grained particles defining SPM weight content are removed from the transport pathway. Abrupt settling of coarse material give rise to sand bars (Fig. 8). Further, with the river plume spreading further offshore, the flow velocity decreases to below the threshold where SPM remains in suspension and instead starts to settle. This is reflected in sediment sorting with a reduction of particle dimension in bottom sediments in an eastward direction (Fig. 8). The river alluvial fan of the Sardakhsko-Trofimovskaya channel outlets is well defined (Figs. 1, 3, 4, 5).

There was much less input of OC from erosion of coastal ice-complex in summer of 2008 compared to summers of 2000, 2005-2007. The ice-complex of Muostakh Island in 2008 did not experience considerable hydrodynamic impacts that is necessary for erosional input to the coastal sea. As a result, the velocity of shore regression was considerably slower and normal thermoabrasion processes were replaced by processes of thermodenudation and solifluction. In the absence of surges that normally wash thawing material out to sea, shore ledges were in 2008 instead blocked by debris from thawing of ice-complexes (Fig. 10). Thus, in summer 
of 2008 the SPM content in nearshore waters around Muostakh Island was reduced $\sim 150$ times compared with summer of 2005, and did not exceed $4 \mathrm{mgl}^{-1}$ (Figs. 4, 5, 10). The isotopic composition of POC in the water column around the island was lighter (more negative) than normal ( -26.4 to $-28.5 \%$ ) and pointed to a river source of SPM (Goni et al., 2005; Rachold et al., 1999) (Fig. 6). This "mean range" is typical for the Buor-Khaya Gulf (Stein, 2000; Stein et al., 2004; Rachold et al., 1999; Mueller-Lupp et al., 2000; Semiletov et al., 1999, 2000; Dudarev et al., 2006), except for summer 2008 when a strong and light river-borne signal was detected as far north as the Novosibirsky Arc (discussed in detail in companion papers written by Alling et al. (2010) and Sánchez-García et al. (2011). This is also in agreement with molecular OC data described in the sister paper by Karlsson et al. (2011). Thus, in 2008 the alluvial source dominated the SPM distribution in the Buor-Khaya Gulf (i.e., Type II sedimentation regime).

\subsection{Sources, transport and distribution of organic matter in the Buor-Khaya Gulf}

The summertime POC concentrations in surface waters of the Buor-Khaya Gulf were similar during the different types of sedimentation (range of $0.13-2 \mathrm{mg} \mathrm{l}^{-1}$ ) but the spatial distributions were different (Fig. 6). Under the Type I sedimentation regime (erosion and accumulation), highest POC levels were well-confined to a North-South band east of the delta, prodelta and around Muostakh island (Fig. 6). This is likely reflecting remobilization of OC from bottom sediments and input of OC from erosion-retreating coastal icecomplexes. Under Type II sedimentation regime (accumulation), highest POC levels were instead defined in an eastward extending river plume from the mouth of the SardakhskoTrofimovskaya delta channel system to the interior BuorKhaya Gulf (Fig. 6). Thus the average POC content in surface waters in the central part of the Buor-Khaya Gulf in 2008 were twice as high as in 2005 (Fig. 6). Winter of 2007 had a similar spatial POC distribution as summer 2008 (Type II sedimentation regime), but with much lower concentrations.

The $\delta^{13} \mathrm{C}$ of POC in the surface layer of August 2005 ranged from -26.4 to $-28.5 \%$ (average $-27.1 \%$ ) (Fig. 9). These values are typical for $\delta^{13} \mathrm{C}$-POC from both the Lena River (Stein, 1998, 2000; Mueller-Lupp et al., 2000; Rachold et al., 1999, Semiletov, 1999; Dudarev et al., 2006a, b, c; Sanchéz-García et al., 2011; Semiletov et al., 2011a) and from eroding ice-complex (Naidu et al., 2000; Mueller-Lupp et al., 2000; Semiletov et al., 2005; Dudarev et al., 2006c). In summertime the dominant source of $\mathrm{OC}$ is terrestrial carbon, while the marine biogenic carbon plays a small role in the Laptev Sea shallow oligotrophic waters (Heiskanen et al., 1996, Sorokin and Sorokin, 1996). The bottom sediments of the prodelta have a similar $\delta^{13} \mathrm{C}$ signal $(-26 \%$ to $-27 \%$; Fig. 9), which is likely a mixture of terrigenous OC from coastal erosion and river discharge. Figure 11 shows the relationship between $\delta^{13} \mathrm{C}$ values of POC and POC concentrations in the water column. The linear correlations suggest two end-member mixing processes with the two hypothetical endmembers being allochthonous and autochthonous organic matter.

The molar organic carbon/total nitrogen ratios $(\mathrm{C} / \mathrm{N})$ of SPM and bottom sediments were comparable, ranging from 9.1 to 15.9 (average $11.6, n=19 ; R^{2}=0.88 ; 2$-sided t-test, $t=10.4, p<0.001$ ) and 10.4 to 15.4 (average $12.7, n=12$; $R^{2}=0.91 ; 2$-sided t-test, $\left.t=8.9, p<0.001\right)$. Higher $\mathrm{C} / \mathrm{N}$ ratios were consistent with their terrestrial nature (Guo et al., 2004; Lobbes et al., 2000; Stein et al., 2004). Taken together, all of this is consistent with the sedimentary OC material in the Buor-Khaya Gulf with Type I sedimentation having several main sources: river alluvium, ice-complex and SPM remobilized from the bottom.

The $\delta^{13} \mathrm{C}$ of POC during Type II sedimentation varied greatly between summer 2008 conditions (as depleted as $-32.2 \%$ ) and winter 2007 conditions as heavy as $-23.6 \%$ (Fig. 10). The only similarity between summer and winter is that the eastward extending river plume is visible in the $\delta^{13} \mathrm{C}$ signals. In the winter period, there is a sharp gradient centered on the outer prodelta, with $\delta^{13} \mathrm{C}$ values getting heavier eastward. This presumably reflects strong terrestrial influence from the river (delta side has value of -28 to $-\%$ o) while at the marine side of the section, the values are -24.2 to $-24.5 \%$, pointing to a mixture of terrigenous and marine sources (Figs. 9, 11). The heavy isotope values could be explained by contribution from sea-ice algae (Stein et al., 2004). The $\mathrm{C} / \mathrm{N}$ molar ratio of SPM ranging from 5.6 to 12.9 (average $8.9, n=45 ; R^{2}=0.81 ; 2$-sided ttest, $t=21.4, p<0.001)$ and of bottom sediments ranging from 8.2 to 19.3 (average $14.8, n=39 ; R^{2}=0.878 ; 2$-sided t-test, $t=7.4, p<0.001)$. More heavier signal of SPM C/N ratios then in summer conditions suggest appearance of marine (autochthonous) source (Fig. 11).

Despite summer conditions during 2008, starting $\delta^{13} \mathrm{C}$ POC values in the delta/prodelta were similar, but became more and more depleted to fall below $-30 \%$ over large areas in the central and northeast Buor-Khaya Bay (Figs. 9, 11). It has recently been argued that the fluvial organic matter is exported in two physical forms; as organic-rich lowdensity flocculates that stay suspended over long distances and as organic coatings on mineral particles, which are more rapidly settling (Vonk et al, 2010a, b). In the anomalous summer of 2008 (see also Alling et al., 2010; Sanchéz-García et al., 2011) the $\delta^{13} \mathrm{C}$-POC was river-borne and much lighter, in agreement with molecular OC data (Karlsson et al., 2011).

The $\delta^{13} \mathrm{C}$ of surface sediments are consistent with a heavier $\delta^{13} \mathrm{C}$ fraction settling out to balance the depleted $\delta^{13} \mathrm{C}$ being transported further offshore with surface waters (Fig. 9). An additional, possibly complementary, explanation of the depleted $\delta^{13} \mathrm{C}$-POC in surface waters of 2008 is that they reflect (also buoyant) phytoplankton and its debris. 
Photosynthesis that has occurred in the river is known to produce depleted $\delta^{13} \mathrm{C}$ (Rachold et al., 1999; Semiletov et al., 2011a). The depleted $\delta^{13} \mathrm{C}$-POC is also consistent with coastal primary production using excess fluvial DIC carrying a depleted $\delta^{13} \mathrm{C}$ relative to marine DIC and thus imprinting a negative bias of marine phytoplankton $\delta^{13} \mathrm{C}$. This was hypothesized to explain similarly depleted $\delta^{13} \mathrm{C}-\mathrm{POC}$ far offshore in the Laptev and East Siberian Sea, that also matched with depletion of other nutrients (Alling et al., 2010; Sánchez-García et al., 2011).

Erosion-accumulation type of sedimentation processes are characterized by drastic increase of the surface sediment OC concentration from $0.1 \%$ in coarse sands up to $5-6 \%$ in fine sediments of the prodelta foot and Muostakh Island slope. Accumulative type of sedimentation is characterized by settling of alluvial sediment material increasing the surface sediment OC from $\sim 0.1 \%$ up to $8-9 \%$ in the prodelta (Fig. 6). Genesis of bottom sediments organic matter in the BuorKhaya Gulf points at a mixed source with a prevalent contribution of products of ice-complex disintegration and river alluvium with $\delta^{13} \mathrm{C}$ of $\mathrm{C}-25 \%$ o to $-27 \%$ (Fig. 11).

A $\delta^{13} \mathrm{C}$ signal heavier than $-24 \%$ was confined to grey sands of the underwater thermo-abrasive and accumulative terrace adjoining the Bykovskiy Peninsula, the southeast part of Muostakh Island and in sands on the beach of the central and southern part of eastern shore of Muostakh Island. The question of genesis of these sands remains open for discussion. We hypothesize, based on mineralogic and X-ray structural results (Fig. 12), that the organic fraction producing a heavy isotopic signal originates from metamorphizedshales of Permian (299-255 Myr ago) deposits. Such Permian deposits were uncovered by boreholes, and in some places (the Bykovskiy channel) even exposed on the surface (Lazko, 1975).

Thus, we can state that the erosion-accumulation regime of sedimentation is characterized by dynamics of eroded POC and anomalously high OC content in the surface sediments in the prodelta foot and Muostakh Island slope, while the accumulative regime is characterized by alluvial POC transport and enhanced OC content near the river mouth.

\section{Conclusions}

This investigation has demonstrated the need to make interannual observations of high spatial resolution to deduce coastal sediment dynamics and OC transport and distribution processes on the wind-driven East Siberian Arctic shelf seas. Based on long-term data (2000-2008) two types of sedimentation regimes have been revealed in connection with different dominant hydrometeorological conditions: (1) erosionaccumulation, and (2) accumulation.

The erosion-accumulation conditions were observed during the short ice-free period of the year (including all expeditions in late August of 1999-2007). This is believed to be the most common and quantitatively most important mechanism for SPM and terrestrial POC delivery to these coastal systems. In this mechanism, terrigenous sources of SPM and POC prevail, originating from thermoabrasion of shores (coastal ice-complex), river sedimentary material and remobilized material from the bottom (high wind/mixing ocean conditions). During the erosion-accumulation sedimentation regime, highest POC content was found outside the mouth of the delta channel, over the prodelta and around the rapidly eroding Muostakh Island. The highest OC content in surface sediments exists off the prodelta and in sediments around Muostakh Island with its eroding ice-complex. Under such conditions terrigenous sources of SPM and POC stem predominantly from thermal erosion of coastal ice complex, remobilized bottom sediments, and river discharge.

The accumulation sedimentation regime develops under ice-covered (winter) conditions and in rare instances during the ice-free period (e.g. August 2008: calm/low wind conditions). Under these accumulation conditions, highest surface water POC contents are confined by the river plume opposite the mouth of the Sardakhsko-Trofimovskaya delta channel. Accumulation type of sedimentation is characterized by settling of fluvial sediment OC in Sardakhski-Trofimovsky sector of the prodelta. In Type 2 winter, combined terrigenous and marine-biogenic SPM and POC sources is dominating due to relatively low overall terrigenous input (April 2007). In Type 2 summer, river alluvium is also the major SPM and POC source (August 2008). The water column SPM and POC loadings vary by more than a factor of two between the two regimes.

Acknowledgements. This work was supported by the Far Eastern Branch of the Russian Academy of Sciences (FEBRAS), the International Arctic Research Center (IARC) of the University of Alaska Fairbanks, by the Cooperative Institute for Arctic Research through the National Oceanic and Atmospheric Administration (NOAA) Cooperative Agreement NA17RJ1224; the U.S. National Science Foundation (Nos. OPP-0327664, OPP-0230455, ARC-1023281, ARC-0909546); the NOAA Office of Oceanic and Atmospheric Research (OAR) Climate Program Office (NA08OAR4600758); and by the Russian Foundation for Basic Research (Nos. 07-0564819, 08-05-00184, 08-05-00191, 10-05-00996, 11-05-00781, 11-05-12021, 11-05-12027, 11-05-12028, 11-05-12032). The International Siberian Shelf Study (ISSS) 2008 cruise was carried out with logistic support from the Knut and Alice Wallenberg Foundation and from the Swedish Polar Research Secretariat and the Arctic Co-Op Program of the Nordic Council of Ministers (331080-70219). We are grateful to Valentin Sergienko, Gunter Weller, Syun Akasofu, and Larry Hinzman for their support of our work in the Siberian Arctic. We thank Leif Anderson for his useful comments. We acknowledge Dmitry Mel'nichenko, Head of the Tiksi Hydrobase, and Elena Streletskaya, Director of the Scientific Agency Arctic Marine Exploration, for their logistic support. Special thanks for Candace O'Connor for English editing.

Edited by: L. Anderson 


\section{References}

Antonov, V. S.: Mouth area of the Lena river (hydrological sketch), Leningrad, Hydrometizdat, 1-107, 1987 (in Russian).

Are, F. E.: Thermoabrasion of sea coasts, Novosibirsk, Nauka, 1171, 1985 (in Russian).

Are, F. E. and Reimnitz, E.: An overview of the Lena river Delta setting: geology, tectonics, geomorphology, and hydrology, J. Coastal Res. 16, 1083-1093, 2000.

Alabyan, A. M., Chalov, R. S., Korotaev, V. N., Sidorchuk, A. Yu., and Zaitsev, A. A.: Natural and technogenic water and sediment supply to the Laptev SEA, Rep. Polar Res., 182, 265-271, 1995.

Alling, V., Sánchez-García, L., Porcelli, D., Pugach, S. P., Vonk, J. E., Dongen, D., Mouth, C. M., Anderson, L. G., Sokolov, A., Andersson, P., Humborg, C., and Semiletov, I. P.: Nonconservative behavior of dissolved organic carbon across the Laptev and East Siberian seas, Global Biogeochem. Cy., 24, GB4033, doi:10.1029/2010GB003834, 2010.

Beach, R. A. and Sternberg, R. W.: Suspended Sediment transport in the surf zone: response to the incident wave and Longshore current interaction, Mar. Geol., 108, 275-294, 1992.

Bowden, K. F.: Physical oceanography of coastal waters, Ellis Horwood Ltd., Chichester, 1-302, 1983.

Charkin, A. N., Dudarev, O. V., Semiletov, I. P., Vonk, J., SánchezGarcía, L., Gustafsson, Ö., Andersson, P., and Shakhova, N.: Sedimentation in the Lena river delta and adjacent part of the Laptev Sea, Geophys. Res. Abstr., 11, EGU2009-3341, EGU General Assembly, 2009.

Charkin, A. N., Dudarev, O. V., Semiletov, I. P., Gustafsson, Ö., Vonk, J., Sánchez-García, L., and Krukhmalev, A.: Seasonal variability of particulate material concentration and its composition in the Buor-Khaya Gulf, Laptev Sea, Geophys. Res. Abstr., 12, EGU2010-6179, EGU General Assembly, 2010.

Dudarev, O., Semiletov, I., Botsul, A., and Charkin, A.: Modern sedimentation in the coastal cryolithozone of the Dmitry Laptev Strait/East-Siberian Sea, Pacific Geology, 22(1), 51-60, 2003 (translated into English).

Dudarev, O. V., Charkin, A. N., Semiletov, I. P., Shilo, I. N., Salyuk, A. N., and Spivak, E. A.: The current state of submarine island relicts on the East Siberian Shelf, Doklady Earth Sciences, 419, 255-261, 2006a (translated in English).

Dudarev, O. V., Semiletov, I. P., and Charkin, A. N.: Particulate material composition in the Lena River-Laptev Sea system: scales of heterogeneities, Doklady Earth Sciences, 411A, 1445-1451, 2006b (translated in English).

Dudarev, O. V., Semiletov, I. P., Charkin, A. N., and Botsul, A. I.: Deposition settings on the continental Shelf of the East Siberian Sea, Doklady Earth Sciences, 409A, 1000-1005, 2006c.

Eicken, H., Dmitrenko, I., Tyshko, K., Darovskikh, A., Dierking, W., Blahak, U., Groves, J., and Kassens, H.: Zonation of the Laptev Sea landfast ice cover and its importance in a frozen estuary, Global Planet. Change, 48, 55-83, 2005.

Grigoriev, M. N: Criomorphogenesis of the mouth area of the Lena River, Yakutsk, Institute of permafrost study of the Siberian Branch of the Russian Academy of Science, 1-176, 1993 (in Russian).

Grigoriev, M. N. and Kunitsky, V. V.: Ice complex of the Arctic coast of Yakutia as a source of detrital deposits on the shelf, in: Hydrometeorological and biogeochemical researches in Arctic regions, Proc. of the Arctic Regional Centre, edited by: Semile- tov, I. P., Vladivostok, Dalnauka, 2, 109-116, 2000 (in Russian). Goñi, M. A., Yunker, M. B., Macdonald, R. W., and Eglinton, T. I.: The supply and preservation of ancient and modern components of organic carbon in the Canadian Beaufort Shelf of the Arctic Ocean, Mar. Chem., 93, 53-73, 2005.

Guo, L., Semiletov, I., Gustafsson, O., Ingri, J., Andersson, P., Dudarev, O., and White, D.: Characterization of Siberian Arctic coastal sediments: Implications for terrestrial organic carbon export, Global Biogeochem. Cy., 18, GB1036, doi:10.1029/2003GB002087, 2004.

Gustafsson, Ö., Haghseta, F., Chan, C., MacFarlane, J., and Gschwend, P. M.: Quantification of the dilute sedimentary soot phase: Implications for PAH speciation and bioavailability, Environ. Sci. Technol., 31, 203-209, 1997.

Gustafsson, Ö., van Dongen, B. E., Vonk, J. E., Dudarev, O. V., and Semiletov, I. P.: Widespread release of old carbon across the Siberian Arctic echoed by its large rivers, Biogeosciences, 8 , 1737-1743, doi:10.5194/bg-8-1737-2011, 2011.

Hansen, L. F., Stelts, M. L., and Wesolowski, J. J.: Ground-State $(p, n)$ Reactions in Mirror Nuclei and the Quasielastic Model of ( $p, n)$ Reactions, Phys. Rev., 143, 800-807, 1966.

Heiskanen, A.-S., Tamminen, T., and Gundersen, K.: The impact of planktonic food web structure on nutrient retention and loss from a late summer pelagic system in the coastal northern Baltic Sea, Mar. Ecol. Prog.-Ser., 145, 195-208, 1996.

Ivanov, V. V. and Piskun, A. A.: Distribution of river water and suspended sediment loads in the deltas of rivers in the basins of the Laptev and East-Siberian Seas, in: Land-Ocean system in the Siberian Arctic: Dynamics and history, edited by: Kassens, H., Bauch, H. A., Dmitrenko, I. A., Eicken, H., Hubberten, H.-W., Melles, M., Thiede, J., and Timokhov, L. A., Springer-Verlag, Berlin Heidelberg, 239-250, 1999.

Karlsson, E. S., Charkin, A., Dudarev, O., Semiletov, I., Vonk, J. E., Sánchez-García, L., Andersson, A., and Gustafsson, Ö.: Carbon isotopes and lipid biomarker investigation of sources, transport and degradation of terrestrial organic matter in the Buor-Khaya Bay, SE Laptev Sea, Biogeosciences, 8, 1865-1879, doi:10.5194/bg-8-1865-2011, 2011.

Lazko, E. M.: Regional Geology of the USSR, The Asian part, volume 2, Moscow, Nedra, 1975 (in Russian).

Lobbes, J. M., Fitznar, H. P., and Kattner, G.: Biogeochemical characteristics of dissolved and particulate organic matter in Russian rivers entering the Arctic Ocean, Geochim. Cosmochim. Ac., 64, 2973-2983, 2000.

Leontyev, I. O.: Coastal dynamics: waves, currents, flows of detrital deposits, Moskow, GEOS, 1-272, 2001 (in Russian).

Longinov, V. V.: Sketches of Lithodynamics of the Ocean, Moscow, Nauka, 1-243, 1973 (in Russian).

Mueller-Lupp, T., Bauch, H. A., Erlenkeuser, H., Hefter, J., Kassens, H., and Thiede, J.: Changes in the deposition of terrestrial organic matter on the Laptev Sea shelf during the Holocene: evidence from stable carbon isotopes, Int. J. Earth Sci., 89, 563$568,2000$.

Naidu, A. S., Cooper, L. W., Finney, B. P., Macdonald, R. W., Alexander, C., and Semiletov, I. P.: Organic carbon isotope ratios $\left(\delta^{13} \mathrm{C}\right)$ of Arctic Amerasian continental shelf sediments, Int. J. Earth Sci., 89, 522-532, 2000.

Navigational book of the Laptev Sea, GUNIO, St.-Petersburg, 1278, 1997 (in Russian). 
Petelin, V. P.: New method of water-mechanical analyze of marine bottom sediment, Oceanology, 1, 143-148, 1961 (in Russian).

Pipko, I. I., Pugach, S. P., Dudarev, O. V., Charkin, A. N., and Semiletov, I. P.: Carbonate parameters of the Lena River: Characteristics and Distribution, Geochem. Int., 48, 1131-1137, 2010.

Rachold, V. and Hubberten, H.-W.: Carbon isotope composition of particulate organic material in East Siberian rivers, in: LandOcean system in the Siberian Arctic: Dynamics and history, edited by: Kassens, H., Bauch, H. A., Dmitrenko, I. A., Eicken, H., Hubberten, H.-W., Melles, M., Thiede, J., and Timokhov, L. A., Springer-Verlag, Berlin Heidelberg, 224-237, 1999.

Rachold, V., Grigoriev, M. N., Are, F. E., Solomon, S., Reimnnitz, E., Kassens, H., and Antonow, M.: Coastal erosion vs. riverine sediment discharge in the Arctic shelf seas, Int. J. Earth Sci., 89, 450-460, 2000.

Richter-Menge, J. and Overland, J. E.: Arctic Report Card 2010, http://www.arctic.noaa.gov/reportcard, 2010.

Sánchez-García, L., Alling, V., Pugach, S., Vonk, J., van Dongen, B., Humborg, C., Dudarev, O., Semiletov, I., and Gustafsson, Ö.: Inventories and behavior of particulate organic carbon in the Laptev and East Siberian seas, Global Biogeochem. Cy., 25, GB2007, doi:10.1029/2010GB003862, 2011.

Savelieva, N. I., Semiletov, I. P., Vasilevskaya, L. N., and Pugach, S. P.: A climate shift in seasonal values of meteorological and hydrological parameters for Northeastern Asia, Prog. Oceanogr., 47, 279-297, 2000.

Semiletov, I. P.: Destruction of the coastal permafrost as an important factor in biogeochemistry of the Arctic shelf waters, Dokl. Earth Sci., 368, 679-682, 1999 (translated in English).

Semiletov, I. P., Savelieva, N. I., Weller, G. E., Pipko, I. I., Pugach, S. P., Gukov, A. Y., and Vasilevskaya, L. N.: in: The Freshwater Budget of the Arctic Ocean, NATO Meeting/NATO ASI Series, Dordtrecht, Kluwer Acad. Publ., 323-366, 2000.

Semiletov, I. P., Dudarev, V. Luchin, A., Charkin, K., Shin, K.-H., and Tanaka, N.: The East Siberian Sea as a transition zone between Pacific-derived waters and Arctic shelf waters, Geophys. Res. Lett., 32, L10614, doi:10.1029/2005GL022490, 2005.
Semiletov, I. P., Pipko, I. I., Shakhova, N. E., Dudarev, O. V., Pugach, S. P., Charkin, A. N., McRoy, C. P., Kosmach, D., and Gustafsson, Ö.: Carbon transport by the Lena River from its headwaters to the Arctic Ocean, with emphasis on fluvial input of terrestrial particulate organic carbon vs. carbon transport by coastal erosion, Biogeosciences, 8, 2407-2426, doi:10.5194/bg8-2407-2011, 2011a.

Semiletov, I. P., Shakhova, N. E., Sergienko, V. I., Pipko, I. I., and Dudarev, O. V.: On Carbon Transport and Fate in the East Siberian Arctic land-shelf-atmosphere system, Environ. Res. Lett., submitted, 2011b.

Shepard, F. P.: Nomenclature based on sand-silt-clay ratios, J. Sediment. Petrol., 24, 151-158, 1954.

Sidorov, I. S.: Features of forming of hydrochemical regime of mouth area of the Lena River and southeast part of the Laptev Sea, synopsis of thesis Rostov-on-Don, 1-24, 1992 (in Russian).

Sorokin, Y. I. and Sorokin, P. Y.: Plankton and primary production in the Lena River estuary and in the south-eastern Laptev Sea, East. Coast. Shelf Sci., 43, 399-418, 1996.

Stein, R.: Circum Arctic river discharge and its geological record, Int. J. Earth Sci., 89, 447-616, 2000.

Stein, R. and Fahl, K.: The Laptev Sea: Distribution, sources, variability and burial of organic carbon, in: The Organic Carbon Cycle in the Arctic Ocean, edited by: Stein, R. and Macdonald, R. W., Springer, 213-237, 2004.

Vonk, J. E., Sánchez-García, L., Semiletov, I., Dudarev, O., Eglinton, T., Andersson, A., and Gustafsson, Ö.: Molecular and radiocarbon constraints on sources and degradation of terrestrial organic carbon along the Kolyma paleoriver transect, East Siberian Sea, Biogeosciences, 7, 3153-3166, doi:10.5194/bg-73153-2010, 2010a.

Vonk, J. E., van Dongen, B. E., and Gustafsson, Ö.: Selective preservation of old organic carbon fluvially released from sub-arctic soils, Geophys. Res. Lett., 37, L11605, doi:10.1029/2010GL042909, 2010b. 